\title{
Extraction, purification, kinetic and thermodynamic properties of urease from germinating Pisum Sativum L. seeds
}

Mohamed E EL-Hefnawy ${ }^{1,3^{*}}$, Mohamed Sakran ${ }^{2,3}$, Ali I Ismail ${ }^{1}$ and Eman Fahmy Aboelfetoh ${ }^{3}$

\begin{abstract}
Background: Urease, one of the highly efficient known enzymes, catalyzes the hydrolysis of urea into ammonia and carbon dioxide. The present study aimed to extract urease from pea seeds (Pisum Sativum L). The enzyme was then purified in three consequence steps: acetone precipitation, DEAE-cellulose ion-exchange chromatography, and gel filtration chromatography (Sephacryl S-200 column).

Results: The purification fold was 12.85 with a yield of $40 \%$. The molecular weight of the isolated urease was estimated by chromatography to be 269,000 Daltons. Maximum urease activity $(190 \mathrm{U} / \mathrm{g})$ was achieved at the optimum conditions of $40^{\circ} \mathrm{C}$ and $\mathrm{pH}$ of 7.5 after 5 min of incubation. The kinetic parameters, $K_{m}$ and $V_{\text {max }}$ were estimated by Lineweaver-Burk fits and found to be $500 \mathrm{mM}$ and $333.3 \mathrm{U} / \mathrm{g}$, respectively. The thermodynamic constants of activation, $\Delta \mathrm{H}, E_{a}$, and $\Delta \mathrm{S}$, were determined using Arrhenius plot and found to be $21.20 \mathrm{~kJ} / \mathrm{mol}$, $23.7 \mathrm{~kJ} / \mathrm{mol}$, and $1.18 \mathrm{~kJ} / \mathrm{mol} / \mathrm{K}$, respectively.

Conclusions: Urease was purified from germinating Pisum Sativum L. seeds. The purification fold, yield, and molecular weight were determined. The effects of $\mathrm{pH}$, concentration of enzyme, temperature, concentration of substrate, and storage period on urease activity were examined. This may provide an insight on the various aspects of the property of the enzyme. The significance of extracting urease from different sources could play a good role in understanding the metabolism of urea in plants.
\end{abstract}

Keywords: Urease, Enzyme activity, Enzyme purification, Pisum Sativum L, Pea seeds

\section{Background}

Catalyzing the hydrolysis of urea into ammonia and carbon dioxide, ureases (urea amidohydrolases, EC 3.5.1.5) are a one of known highly efficient enzymes that belong to amidohydrolase and phosphotriesterase superfamily [1]. Several reports have been published on the extraction of urease from various bacteria [2-4], and plants [5-11]. The high molecular mass nickel-containing metalloenzyme [12] is believed to play an important role in the nitrogen transport cycle in plants [13]. In addition, the enzyme decomposes urea formed from arginase that is found in seed germination [14]. Urease is also important in human

\footnotetext{
* Correspondence: malhefnawy@kau.edu.sa

'Department of Chemistry, Rabigh College of Science and Arts, King

Abdulaziz University, P.O. Box 344, Rabigh 21911, Saudi Arabia

${ }^{3}$ Department of Chemistry, Faculty of Science, Tanta University, Tanta 31527

Egypt

Full list of author information is available at the end of the article
}

bodies due to the fact that many urinary tract and gastroduodenal diseases [15,16], including cancer $[17,18]$, are related in some ways to this enzyme. The increased need in finding proper ways to remove urea from different environments brought great attractions in the biotechnology field [19]. Some of urease's applications include treatment of industrial waste [20], the industry of alcoholic beverages [21], use in haemodialysis [22,23], and its potential use in space missions as life supporter [24].

The plant and fungal ureases are homo-oligomeric with identical proteins repetition. On the other hand, the bacterial ureases are composed of complex repetitions of two or three subunits of different sizes [25]. The crystal structure of protein is often the key to its enzyme function. This configuration is governed by its primary structure and environment. Any environmental factor, that alters the shape of the enzyme or blocks the access to the active site in substrate, will affect enzyme activity. 
Such environmental factors include matrix salt concentration, $\mathrm{pH}$, temperature, substrate concentration, activators, and inhibitors [26,27].

The purpose of this study is to extract, purify, and characterize urease from plant source (pisum sativum L). Also, the activity of the enzyme was evaluated based on the change of the environmental factors that carried out during the purification procedure. This may provide an insight on the various aspects of the property of the enzyme.

\section{Methods}

Pisum Sativum L. seeds were obtained from faculty of agriculture, Kafr Elshaikh University, Kafrelshaikh city, Egypt. The seeds were soaked in distilled water for 6 hours, germinated in the dark at $22^{\circ} \mathrm{C}$ for $2,4,6,8,10,12,14$ and 16 days. The germinated seeds were stored separately in deep freezer $\left(-20^{\circ} \mathrm{C}\right)$ for further experimental purposes. Dextran polymer particles (Sephadex G-200), bovine serum albumin (BSA), standard proteins, and DEAE-cellulose were purchased from Sigma Chemicals Ltd., USA. All other chemicals used for this research were of analytical grade. All absorbance measurements were performed using Lambda 35 PerkinElmer UV/V is spectrometer.

\section{Urease extraction and purification}

Unless mentioned otherwise, all of the following procedures were done at $4^{\circ} \mathrm{C}$. Ten grams of germinated seeds of pisum sativum were pasted in a mortar and pestle and then suspended in $40 \mathrm{~mL}$ of $20 \%$ chilled acetone $\left(-20^{\circ} \mathrm{C}\right)$. Occasional stirring for $3 \mathrm{~h}$ was required. Double layer cheese cloth was used for filtrating of the suspension. After 15 minutes of centrifuging of the filtrate, the supernatant was isolated and used as "crude extract".

The urease assay was performed as described by Sharma et al. [28]. Enzyme extract $(0.25 \mu \mathrm{L})$ was added to $10 \mathrm{~mL}$ of urea solution ( $0.4 \mathrm{~g}$ urea in $25 \mathrm{ml}$ of phosphate buffer). One millilitre of the previous solution was added to each test tube containing $5 \mathrm{~mL}$ of Nesslers reagent, and incubated at $40^{\circ} \mathrm{C}$ for $5 \mathrm{~min}$. They were followed by the addition of $1.0 \mathrm{M} \mathrm{HCl}$ to terminate the reaction after specific time. Absorbance measurements were taken for the resulting solutions (at $405 \mathrm{~nm}$ ). The estimation of urease was carried out using the standard curve of ammonium sulphate. One unit of urease activity is defined as "the amount of enzyme required to liberate $1.0 \mu \mathrm{M}$ of $\mathrm{NH}_{3}$ from urea per minute at $\mathrm{pH} 7.5$ and temperature $40^{\circ} \mathrm{C}$ " [29].

Proteins were determined according to Lowry et al. [30] using BSA as standard material. Different concentrations of BSA were prepared ranging from (0 to 25) $\mu \mathrm{g} / \mathrm{mL}$. The linear calibration curve was used to determine the concentration of protein in the assay and estimated for the original sample.

The enzyme was purified to homogeneity by the following successive steps which carried out at $4^{\circ} \mathrm{C}$ :

\section{Acetone precipitation}

The "crude extract" was adjusted to $50 \%$ saturation by addition of acetone (chilled to $-20^{\circ} \mathrm{C}$ ) under constant and gentle stirring. The resulting precipitate was centrifuged, collected, dissolved in minimum volume of pre-cold $50 \mathrm{mM}$ phosphate buffer $(\mathrm{pH}=7.4)$, and finally dialyzed against the same buffer for $24 \mathrm{~h}$. The resulting solution was then centrifuged for $10 \mathrm{~min}$ and the clear supernatant was designated as "crude enzyme solution".

\section{DEAE-cellulose chromatography}

The "crude enzyme solution" was dialyzed against $50 \mathrm{mM}$ phosphate buffer, $\mathrm{pH}$ 7.4. It was then loaded on preequilibrated DEAE-cellulose column $(15 \times 3.0 \mathrm{~cm})$ (with $50 \mathrm{mM}$ phosphate buffer, $\mathrm{pH}$ 7.8). The bound proteins were eluted with a linear gradient of $\mathrm{NaCl}(100-$ $500 \mathrm{mM}$ ), prepared with phosphate buffer, $\mathrm{pH} 7.8$, at a

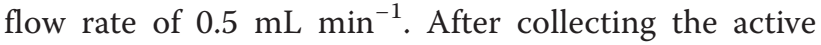
fractions (the fractions that shows urease activity), the proteins binding to the column were eluted using gradient of $(0-0.5 \mathrm{M}) \mathrm{KCl}$ and $(20 \mathrm{mM})$ phosphate buffer, $\mathrm{pH}$ 7.5. The absorbance of these fractions was measured at wavelength of $280 \mathrm{~nm}$. The active fractions were combined and the volume was measured for the determination of the urease activity and protein contents in the assay.

\section{Gel filtration chromatography}

The enzyme obtained from the ion exchange step was concentrated with acetone and loaded on the Sephacryl S-200 column $(1.5 \times 65)$ at a flow rate $30 \mathrm{~mL} / \mathrm{h}$ using $50 \mathrm{mM}$ phosphate buffer, $\mathrm{pH}=7.8$. Five millilitre eleunts were collected. The enzymatically active fractions were pooled and dialyzed against $50 \mathrm{mM}$ phosphate buffer, $\mathrm{pH} 7.4$ for $24 \mathrm{~h}$. The absorbance measurements at $280 \mathrm{~nm}$ were used to determine the protein concentration and urease activity.

\section{Enzyme characterization}

The isolated enzyme activity was characterized and studied as a function of $\mathrm{pH}$, temperature, storage period, enzyme concentration, and substrate concentration using the following procedures:

\section{Determination of molecular weight of urease}

Two millilitres of blue dextran-2000 solution $(6 \mathrm{mg}$ into $3 \mathrm{~mL}$ of PEM buffer $\mathrm{pH}$ 7.5, 0.1 M PIPES, 1 mM EGTA, $1 \mathrm{mM} \mathrm{MgSO} 4$, at $\mathrm{pH}=6.6$; where PIPES is piperazine-N, $\mathrm{N}^{\prime}$-bis(2-ethanesulfonic acid, and EGTA is ethylene glycolbis-( $\beta$-aminoethyl ether)-N,N,N',N'-tetraacetic acid) were passed through Sephacryl S-200 column. $20 \mathrm{mM}$ of PEM buffer $\mathrm{pH} 7.5$ was added. Fractions of $5 \mathrm{ml}$ were eluted and the absorbance at $600 \mathrm{~nm}$ for each fraction was measured. The column void volume $\left(V_{0}\right)$ was determined by 
estimating the total volume of the fractions characterized with the starting point movement of the dextran to climax of absorbance of the blue dextran. Same procedure was done for the standard proteins; BSA, aldolase, catalase, ferrtin, and thyroglobulin. The eluted fractions, which give a maximum absorbance at $280 \mathrm{~nm}$, were determined, and the eluted volume $\left(V_{e}\right)$ was calculated for each standard protein. The linear calibration curve of $\frac{V_{e}}{V_{0}}$ against logarithm value of molecular weight of standard protein was plotted. The curve was used for determining the molecular weight of native urease.

\section{Effect of $\mathrm{pH}$ on the activity of pisum sativum urease} The $\mathrm{pH}$ profile for the purified urease was estimated using urea as a substrate. The $\mathrm{pH}$ range used was from 3 to 10 using $50 \mathrm{mM}$ phosphate buffer.

\section{Effect of storage at $-4^{\circ} \mathrm{C}$ on enzyme activity}

To determine the effect of storage of the enzyme on the urease activity, the enzyme was stored at different time internals of 0-60 days. The enzyme activity was measured after each separate time period.

\section{Effect of different concentration of enzymes}

The optimum enzyme concentration was determined by varying the amount of the pure enzyme.

\section{Effect of temperature}

The optimum temperature for urease activity was determined over the temperatures from 10 to $40^{\circ} \mathrm{C}$ using the standard conditions of the assay.

\section{Thermodynamic studies}

The relationship between the rate of an enzymatic reaction and activation energy is given by the empirical formula of the Arrhenius equation:

$$
E_{a}=\mathrm{R} \cdot \ln \left(\frac{\mathrm{V}_{2}}{\mathrm{~V}_{1}}\right) \cdot\left(\frac{1}{\mathrm{~T}_{1}}-\frac{1}{\mathrm{~T}_{2}}\right)
$$

where $V_{1}$ and $V_{2}$ are the enzyme activities at the temperatures $T_{1}$ and $T_{2} ; E_{a}$ is the energy of activation $\left(\mathrm{kJ} \mathrm{mol}{ }^{-1}\right.$ ) which can be determined from the slope of the Arrhenius plot of $\ln (V)$ against $\frac{1}{T}$.
The activation enthalpy $(\Delta \mathrm{H})$ can be calculated by eqn. 2 .

$$
\Delta H=E_{a}-R T
$$

Finally the entropy $(\Delta S)$ was calculated by eqn 3 (Eyring-Polanyi), which correlates $\Delta \mathrm{H}, E_{a}$, and Arrhenius equation (eqn. 1);

$$
\ln \left(\frac{V_{\max }}{T}\right)=\ln \left(\frac{K_{B}}{h}\right)+\frac{\Delta S}{R}-\frac{\Delta H}{R} \cdot \frac{1}{T}
$$

where $\mathrm{T}, K_{B}$, h, and $\mathrm{R}$ are absolute temperature, Boltzmann constant, Planck constant and gas constant respectively.

\section{Effect of different concentration of substrates}

The effect of urea concentration on the activity of enzyme was examined. Urea solution of different concentration was taken in different test tubes and the enzyme activity was measured. $K_{m}$ and $V_{\max }$ for urease were calculated using Lineweaver-Burk double reciprocal plot [31].

\section{Results \\ Purification of urease}

After 6 days of germination the activity increased gradually and showed maximum activity on the ninth day after germination and then declined rapidly (Data not shown). Therefore, we used the $9^{\text {th }}$ day of germination for further experimental purpose. The results of the purification activity of the germinated pisum sativum seed urease were summarized in Table 1 . The total activity which represents the summation of the activity of all proteins in the extract samples showed a decrease over the period of the purification procedure. However, the most important parameter is the specific activity of the extracted enzyme which represents the actual activity of the active proteins only. The results showed an increase in the specific activity throughout the purification steps. The final purification fold achieved was nearly 12.85 . The specific activity after finishing the purification was 5833.3 $\mathrm{Umg}^{-1}$.

Ion-exchange chromatography was carried out using the anion exchanger DEAE-cellulose. Approximately $20 \mathrm{ml}$ of crude extract was passed through the column. As shown in Figure 1a, four peaks of proteins appeared

Table 1 Yield and purification fold at different steps of purification of urease from germinated pisum sativum seeds

\begin{tabular}{llllll}
\hline Step of purification & Total protein $(\mathbf{m g} / \mathbf{m l})$ & Total activity (Units) & Specific activity (U/mg) & Yield (\%) & Purification fold \\
\hline Crude extract & 22 & 10000 & 454.5 & 100 & 1 \\
Acetone precipitation and dialysis & 12 & 7500 & 625 & 75 & 1.3 \\
Ion exchange DEAE-cellulose & 3.1 & 5000 & 1613 & 50 & 3.5 \\
Gel filtration Sephacryl S-200 & 0.72 & 4200 & 5833 & 42 & 12.85 \\
\hline
\end{tabular}



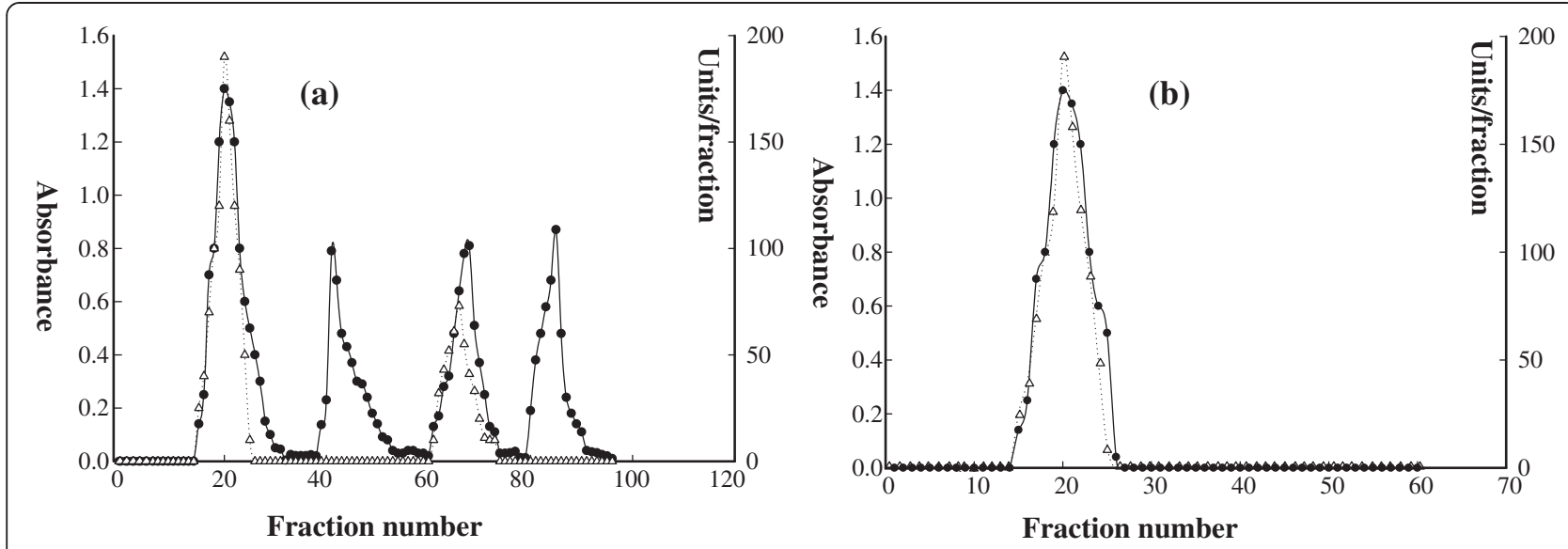

Figure 1 A typical elution profile for the ion exchange chromatography of Pisum Sativum L. urease from, (a) only DEAE-cellulose column $(15 \times 3.0 \mathrm{~cm})$, and (b) DEAE-Cellulose followed by Sephacryl S-200 column $(90 \times 1.6 \mathrm{~cm}$ i.d.). is for absorbance at $280 \mathrm{~nm}$, and is for urease activity.

at fractions of $20,41,68$, and 85 . Peaks of fraction number 20 and 68 showed urease enzyme activity. The values of the urease activity were of 190 unit/ fraction for the fraction number 20 and 73 unit/ fraction for the fraction number 68. The fractions of the first peak were collected for the gel chromatography separation. The fractions that showed enzyme activity from the gel chromatography filtration were concentrated by dialysis and applied to
Sephacryl S-200 column. At the end of the purification procedure, one peak for protein and enzyme activity was observed at fraction 23 (Figure 2b).

\section{Characterization of the purified Urease Molecular weight determination}

The molecular weight of urease was determined using gel filtration chromatography to be equal to $269,000 \pm$

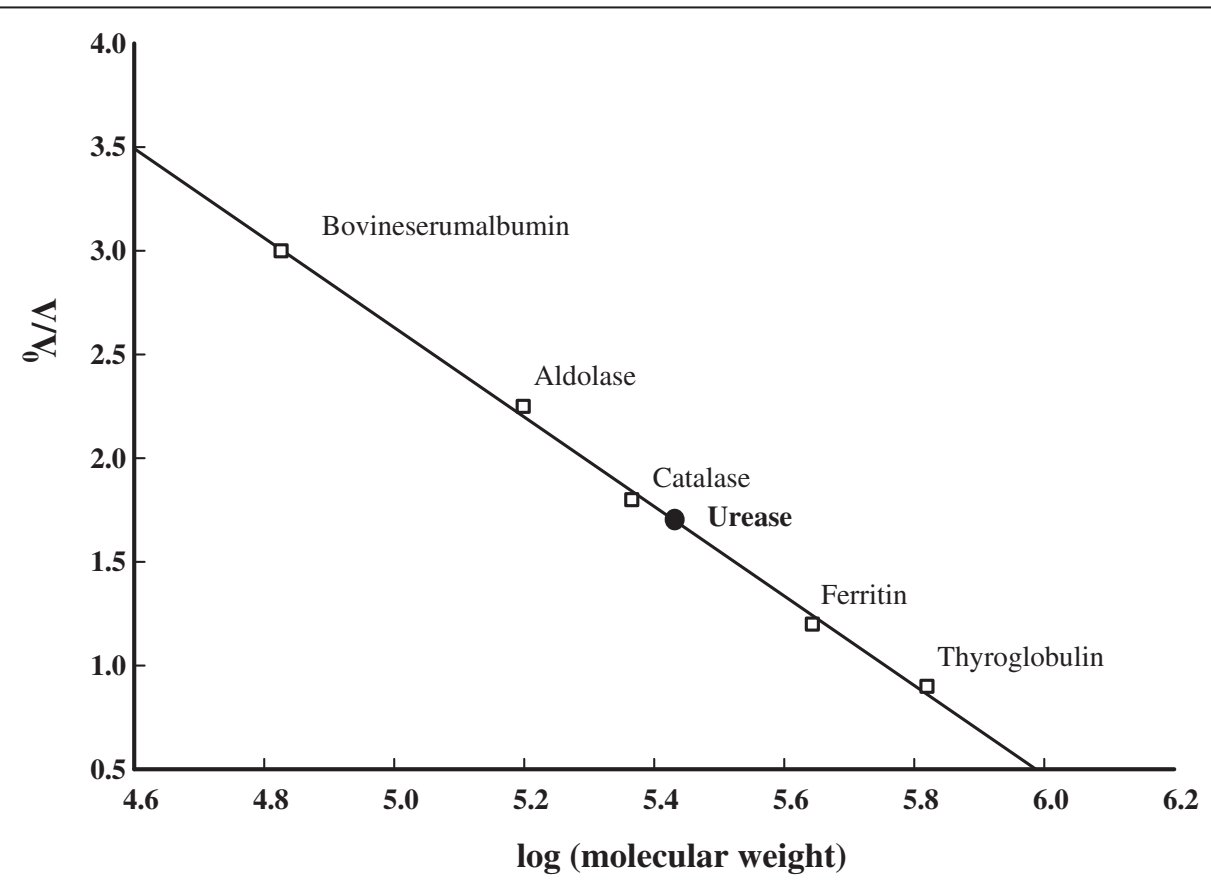

Figure 2 Calibration curve for standard proteins; bovineserum albumin, aldolase, catalase, ferritin, and thyroglobulin using Sephacryl S-200 column. The empty filled squares are for the standard proteins, and the solid sphere is for the urease extracted from the germinating pisum sativum seeds used in this study. 
$200 \mathrm{Da}$ (linearity regression parameter of 5 standard proteins, $R^{2}=0.997$ ) as shown in Figure 2 .

\section{Effect of $\mathrm{pH}$ on the activity of pisum sativum urease}

The $\mathrm{pH}$ profiles for the purified urease were estimated using urea as a substrate. The $\mathrm{pH}$ range used was from 3 to 10 using $50 \mathrm{mM}$ phosphate buffer. The activity of urease was the highest at pH 7.5 (Figure 3a).

\section{Effect of storage period}

The enzyme activity decreased with time even when stored at $-4^{\circ} \mathrm{C}$. It represented $100 \%$ on the first day but decreased to $80 \%$ on the tenth day. However, it retained about $14.1 \%$ even after 2 months. The exponential decay fits showed a half life time of 22.4 days (see Figure $3 \mathrm{~b}$ ).

\section{Effect of enzyme concentration on the activity of pisum sativum urease}

As indicated in Figure 3c, the urease activity increased significantly rapidly by increasing the enzyme concentration until reaches a value of $100 \mathrm{ug} / \mathrm{mL}$. After that the activity kept rising but in slower rate. The maximum activity reached was $102 \mathrm{units} /$ assay at $200 \mathrm{ug} / \mathrm{mL}$ of enzyme.

\section{Effect of temperature on enzyme activity}

Figure $3 \mathrm{~d}$ showed the temperature optimum curve for urease. The complete assays of enzyme were incubated at different temperatures from 10 to $80^{\circ} \mathrm{C}$ for 10 minute. Results showed that urease had an optimum temperature at $40^{\circ} \mathrm{C}$.

\section{Thermodynamic parameters $\left(E_{a}, \Delta H\right.$, and $\left.\Delta S\right)$}

The activation energy $\left(E_{a}\right)$ can be determined from the slope of the empirical formula of the Arrhenious plot of natural logarithm of the urease activity versus the reciprocal value of temperature (see Figure 4a) The activation energy was found to be $23.7 \mathrm{~kJ} / \mathrm{mol}$. Both enthalpy of activation $(\Delta \mathrm{H})$ and entropy of activation $(\Delta \mathrm{S})$ were calculated using Arrhenius plot as shown in Figure $4 \mathrm{~b}$ and were found to be $21.20 \mathrm{~kJ} / \mathrm{mol}, 1.18 \mathrm{~kJ} / \mathrm{mol}$ respectively.
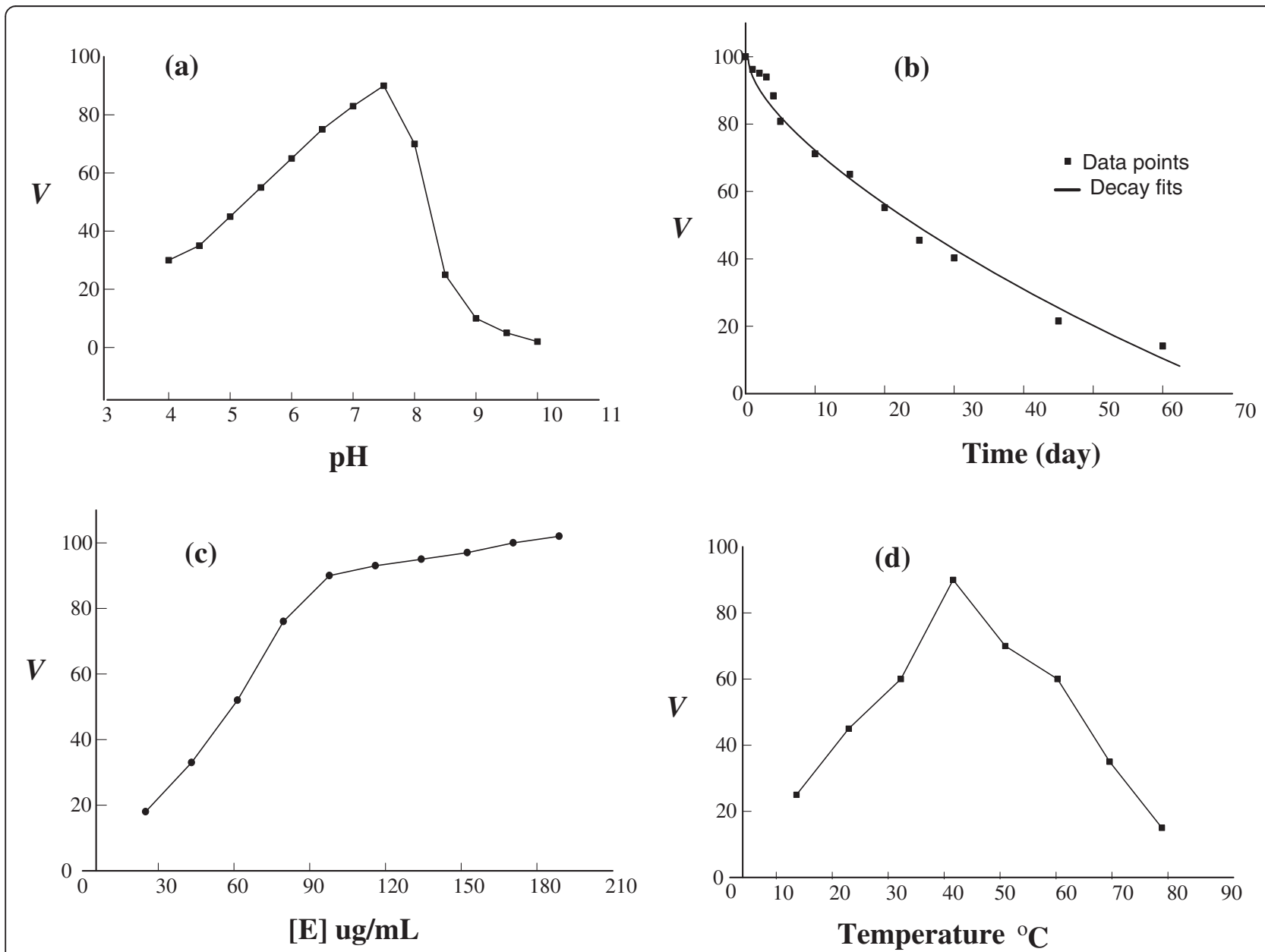

Figure 3 Effect of (a) $\mathrm{pH}$ (at incubation temperature $=40^{\circ} \mathrm{C}$ ), (b) time of storage (at $-4^{\circ} \mathrm{C}$ ), (c) enzyme concentration $(\mathrm{pH}=7.5$, temperature $\left.=40^{\circ} \mathrm{C}\right)$, and $(\mathrm{d})$ temperature $(\mathrm{pH}=7.5)$, on urease activity extracted from Pisum Sativum $L$. seeds. 

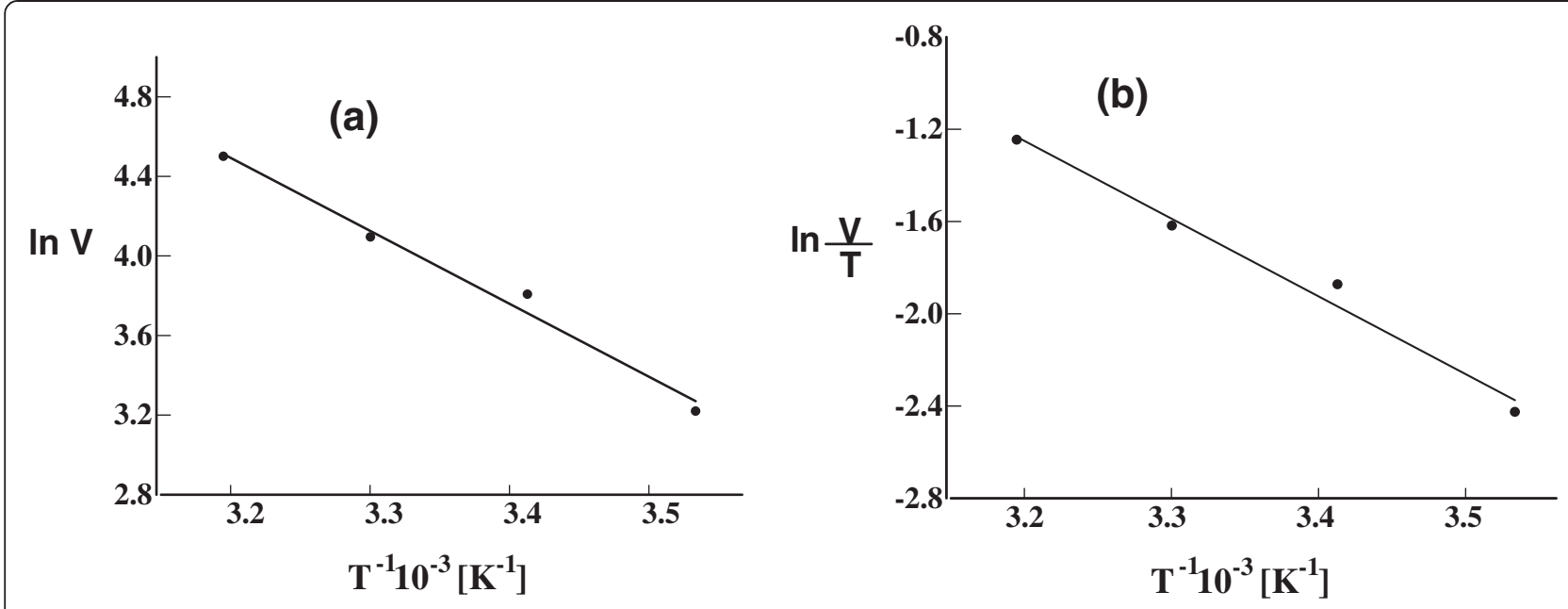

Figure 4 Arrhenius plot for the activity of urease that is extracted from germinating pisum sativum L. seeds, for the calculation of (a) activation energy, and (b) entropy of activation and enthalpy of activation.

Effect of substrate concentration on the activity of pisum sativum urease

As indicated in Figure 5a by increasing urea concentration, the activity increased until nearly constant maximum activity 102 units/assay at $200 \mathrm{mM}$ of substrate. Further increase in urea concentration resulted in a gradual decrease in enzyme activity.

The kinetics constants $\left(K_{\mathrm{m}}\right.$ and $\left.V_{\text {max }}\right)$

The kinetics constants $\left(K_{m}\right.$ and $V_{\max }$ ) for the purified urease were determined by incubating a fixed amount of enzyme with varying the concentration of urea solution (urea used here as substrate). $K_{\mathrm{m}}$ and $V_{\max }$ for urea were calculated using Lineweaver-Burk double reciprocal plot, Figure $5 \mathrm{~b}$, and were found to be $500 \mathrm{mM}$ and $333 \mathrm{U} / \mathrm{g}$, respectively

\section{Discussion}

Urease plays an essential role in the nitrogen metabolism in both germination and seedlings of plants. Two peaks were found to have urease activity. However, the highest activity peak was chosen for further experiments. The low activity peak (high salt peak) has low concentration and low urease ratio that limit our ability to consider it for further experimentation. The fact for having two peaks is unusual. However, as this study is the first to use the germinating pisum sativum seeds, there is a possibility of having more than one isozyme with different elution times and conditions. The results of germinated pisum sativum seed urease, Table 1 , shows that the final purification fold achieved was 12.85 and the specific activity was $5833.3 \mathrm{Umg}^{-1}$. In comparison with other studies, the purification results of germinated chickpea
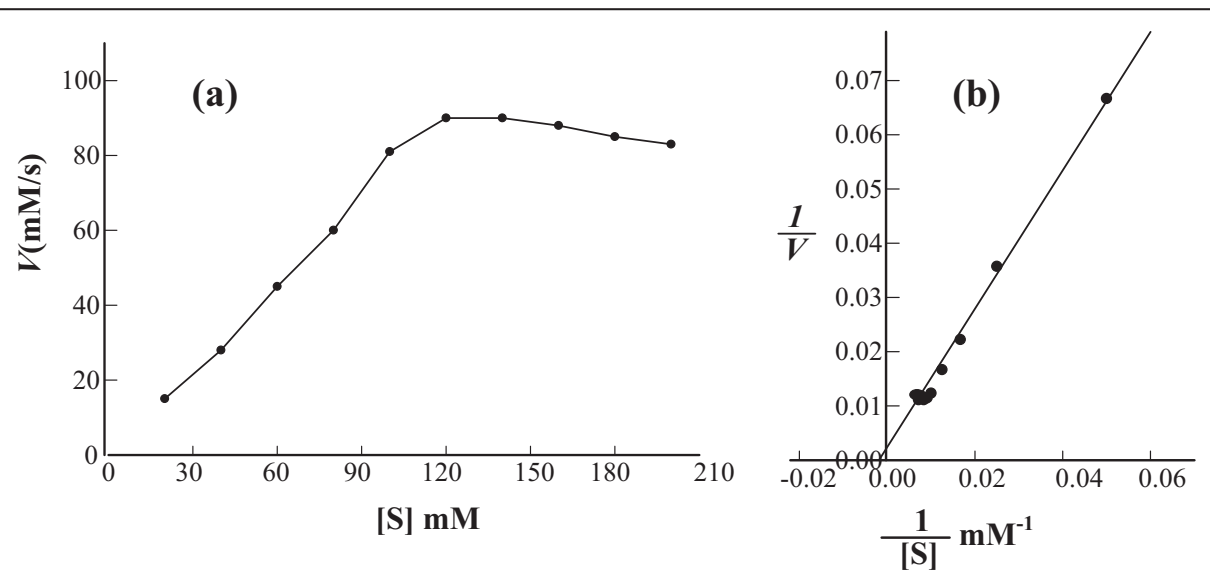

Figure 5 Effect of substrate concentration on the activity of urease extracted from pisum sativum L. seeds. (a) Dependence of initial reaction rate on substrate concentration of urease; $\mathrm{pH} 7.5$, temperature $40^{\circ} \mathrm{C}$. (b) Lineweaver-Burk double reciprocal plot. 
specific activity was 489.57 and the final purification fold was 45 [26]. Also, for Proteus mirabilis urease, the Specific activity of the extracted enzyme was 22932.86 and the final purification fold was 13.86 [32].

The molecular weight of the pisum sativum seeds urease reported in this investigation was $269,000 \mathrm{Da}$, compared to 480,000 Da for jack bean [33], and 540,000 Da for dehusked pigeonpea (Cajanus cajan L.) [7]. The molecular weight of enzymes is known to change relative to the source and even stage of plant growth.

The $\mathrm{pH}$ plays an important role in the activity of enzyme. The urease isolated from Pisum Sativum seed was found to yield maximum activity at pH 7.5 (Figure 3a) which means that the seeds may belong to the category of basic urease. Despite the fact that Mulberry leaves have shown neutral optimum $\mathrm{pH}$ [3], many other studies reported basic $\mathrm{pH}$ as an optimum value for the ectracted urease. For example the optimum $\mathrm{pH}$ was found to be 8 in jack beans [34], pigeonpea [7], pathogenic fungus (Coccidiodes immitis) [35], aspergillus niger [36], and bacillus pasteurii [37]. These results may be explained by the fact that acidic $\mathrm{pH}$ has an inhibitory effect on the enzyme resulting in reducing its activity. Also, the existence of the active sites in amino acids will be influenced by the change in $\mathrm{pH}$ which may alters the ionization of these amino acids [38].

The optimum temperature, where the greatest urease activity carries out, is equal to $40^{\circ} \mathrm{C}$. This result is comparable to several studies, reported by Das et al. [7], and Srivastava et al. [39]. The kinetic energy of molecules increases with an increase in temperature which results in seeding up the rate of reaction. When the temperature was further increased, the molecules of enzyme exceed the barrier of energy. This causes the breakage of hydrogen and hydrophobic bonds that are responsible for maintaining the 3D structure of enzyme $[4,40]$.

The optimum value of substrate concentration, where the urease activity has the largest value, was found to be $120 \mathrm{mM}$. After that the activity starts to gradually decrease. The decrease in the activity could be explained by substrate inhibition at higher urea concentrations. The enzyme showed the highest activity when incubated for 5 min under standard conditions; temperature $=40^{\circ} \mathrm{C}$ and $\mathrm{pH}=7.4$. The rate of hydrolysis of urea increases with increasing urea concentration until reaching a maximum, beyond that hydrolysis activity starts to decrease [41,42]. Loest [43] and Shepard and Lunceford [44] obtained maximum urease activity at $0.25 \mathrm{M}$ and $0.008 \mathrm{M}$ concentration of urea, respectively.

The Kinetics constants $\left(K_{m}\right.$ and $\left.V_{\max }\right)$ for urease extracted from germinated pisum Sativum was calculated using Lineweaver-Burk double reciprocal plot and were found to be $500 \mathrm{mM}$ and $333.3 \mathrm{U} / \mathrm{g}$ respectively. These values indicated a low affinity of substrate to urease.

\section{Conclusions}

Urease was purified from germinating Pisum Sativum L. seeds. The purification fold was 12.85 with a yield of $40 \%$. The molecular weight was estimated as: 269,000 Daltons factors adjusted for its action was $\mathrm{pH} 7.5$, temperature $40^{\circ} \mathrm{C}$, but further studies are required to elucidate its significance in the metabolism of urea in plants.

\section{Abbreviations \\ DEAE: Diethylaminoethanol; BSA: Bovine serum albumin; PEM buffer: $0.1 \mathrm{M}$ PIPES, $1 \mathrm{mM}$ EGTA, and $1 \mathrm{mM}$ MgSO4; PIPES: Piperazine-N,N'-bis(2- ethanesulfonic acid; EGTA: Ethylene glycol-bis-(ß-aminoethyl ether)-N,N,N',N'- tetraacetic acid.}

\section{Competing interests}

The authors declare that they have no competing interests.

\section{Authors' contributions}

ME and MS conceived the study, carried the purification procedure, activity measurements, and drafted the manuscript. Al participated in the activity measurements, coordination, and helped drafting the manuscript. EA participated in the activity measurements, and coordination. All authors read and approved the final manuscript.

\section{Acknowledgements}

The authors would like to thank King Abdulaziz University, Rabigh College of Arts and Science, Tabuk University and Tanta University for offering the required facilities and funding

\section{Author details}

'Department of Chemistry, Rabigh College of Science and Arts, King Abdulaziz University, P.O. Box 344, Rabigh 21911, Saudi Arabia. ${ }^{2}$ Department of Biochemistry, Faculty of Science, Tabuk University, Tabuk, Saudi Arabia. ${ }^{3}$ Department of Chemistry, Faculty of Science, Tanta University, Tanta 31527, Egypt.

Received: 15 April 2014 Accepted: 17 July 2014

Published: 28 July 2014

\section{References}

1. Krajewska B: Ureases I. Functional, catalytic and kinetic properties: a review. J Mol Catal B: Enzym 2009, 59(1-3):9-21.

2. Clemens DL, Lee BY, Horwitz MA: Purification, characterization, and genetic-analysis of mycobacterium-tuberculosis urease, a potentially critical determinant of host-pathogen interaction. J Bacteriol 1995, 177(19):5644-5652.

3. Hirayama C, Sugimura M, Saito H, Nakamura M: Purification and properties of urease from the leaf of mulberry, Morus alba. Phytochemistry 2000, 53(3):325-330.

4. Lubbers MW, Rodriguez SB, Honey NK, Thornton RJ: Purification and characterization of urease from Schizosaccharomyces pombe. Can $J$ Microbiol 1996, 42(2):132-140

5. Balasubramanian A, Ponnuraj K: Purification, crystallization and preliminary X-ray analysis of urease from pigeon pea (Cajanus cajan). Acta Crystallogr Sect F Struct Biol Cryst Commun 2008, 64:662-664.

6. Balasubramanian A, Ponnuraj K: Purification, crystallization and preliminary $\mathrm{X}$-ray analysis of urease from jack bean (Canavalia ensiformis). Acta Crystallogr Sect F Struct Biol Cryst Commun 2009, 65:949-951.

7. Das N, Kayastha AM, Srivastava PK: Purification and characterization of urease from dehusked pigeonpea (Cajanus cajan L.) seeds. Phytochemistry 2002, 61(5):513-521.

8. Krishna BL, Singh AN, Patra S, Dubey VK: Purification, characterization and immobilization of urease from Momordica charantia seeds. Process Biochem 2011, 46(7):1486-1491.

9. Prakash O, Bhushan G: Isolation, purification and partial characterisation of urease from seeds of water melon (Citrullus vulgaris). J Plant Biochem Biotechnol 1997, 6(1):45-47.

10. Tekiner P, Percin I, Ergun B, Yavuz H, Aksoz E: Purification of urease from jack bean (Canavalia ensiformis) with copper (II) chelated poly 
(hydroxyethyl methacrylate-N-methacryloyl-(L)-histidine methyl ester) cryogels. J Mol Recognit 2012, 25(11):549-554.

11. Weber M, Jones MJ, Ulrich J: Optimisation of isolation, and purification of the jack bean enzyme urease by extraction and subsequent crystallization. Food Bioprod Process 2008, 86(C1):43-52.

12. Zambelli B, Musiani F, Benini S, Ciurli S: Chemistry of Ni2+ in Urease: Sensing, Trafficking, and Catalysis. Acc Chem Res 2011, 44(7):520-530.

13. Polacco JC, Holland MA: Roles of urease in plant-cells. Int Rev Cytol 1993, 145:65-103

14. Zonia LE, Stebbins NE, Polacco JC: Essential role of urease in germination of nitrogen-limited arabidopsis-thaliana seeds. Plant Physiol 1995, 107(4):1097-1103.

15. Konieczna I, Zarnowiec P, Kwinkowski M, Kolesinska B, Fraczyk J, Kaminski Z, Kaca W: Bacterial urease and its role in long-lasting human diseases. Curr Protein Pept Sci 2012, 13(8):789-806.

16. Burne RA, Chen YYM: Bacterial ureases in infectious diseases. Microbes Infect 2000, 2(5):533-542.

17. Sekichi F, Fukami K, Takaoka K, Miyake K, Yamamoto T, Tanaka S, Ohn K, Ishikura H, Naruse M, Kawabata A: Correlation between the abundance of Helicobacter pylori-derived urease and expression levels of PAR1 or PAR2 in the gastric tissue isolated from gastric cancer patients. J Pharmacol Sci 2009, 109:172P-172P.

18. Wu C-H, Huang M-Y, Yeh C-S, Wang J-Y, Cheng T-L, Lin S-R: Overexpression of Helicobacter pylori-associated urease mRNAs in human gastric cancer. DNA Cell Biol 2007, 26(9):641-648.

19. Qin Y, Cabral JMS: Review properties and applications of urease. Biocatalys and Biotransform 2002, 20(1):1-14.

20. George S, Chellapandian M, Sivasankar B, Jayaraman K: A new process for the treatment of fertilizer effluent using immobilized urease. Bioprocess Eng 1997, 16(2):83-85.

21. Kobashi K, Takebe S, Sakai T: Removal of urea from alcoholic beverages with an acid urease. J Appl Toxicol 1988, 8(1):73-74.

22. Roberts M: The regenerative dialysis (REDY) sorbent system. Nephrology 1998, 4(4):275-278

23. Lee KB, Boadi DK, Neufeld RJ: Steady-state analysis of a fixed-bed reactor for urea hydrolysis with microencapsulated urease. Chem Eng Sci 1995, 50(14):2263-2273.

24. Schussel LJ, Atwater JE: A urease bioreactor for water reclamation aboard manned spacecraft. Chemosphere 1995, 30(5):985-994.

25. Miyagawa K, Sumida M, Nakao M, Harada M, Yamamoto H, Kusumi T, Yoshizawa K, Amachi T, Nakayama T: Purification, characterization, and application of an acid urease from Arthrobacter mobilis. J Biotechnol 1999, 68(2-3):227-236.

26. Shaela Pervin M, Sarowar Jahan MG, Masud Rana AYKM, Sana NK, Habibur Rahman M, Shaha RK: Effects of some environmental variables on urease in germinating chickpea (Cicer arietinum L.) Seed. I Stress Physiol Biochem 2013, 9(3):345-356.

27. Rektorschek M, Weeks D, Sachs G, Melchers K: Influence of $\mathrm{pH}$ on metabolism and urease activity of Helicobacter pylori. Gastroenterology 1998, 115(3):628-641.

28. Sharma R, Rajput YS, Kaur S, Tomar SK: A method for estimation of urea using ammonia electrode and its applicability to milk samples. J Dairy Res 2008, 75(4):466-470.

29. Zhou J-q, Chen S-h, Ye L, Li W, Jiang X: Study on the Activity and Stability of Urease Immobilized via a Saccharide-Concanavalin a Binding. In Bioinformatics and Biomedical Engineering, 2008 ICBBE 2008 The 2nd International Conference on: 16-18 May 2008; 2008:990-993.

30. Lowry OH, Rosebrough NJ, Farr AL, Randall RJ: Protein measurement with the folin phenol reagent. J Biol Chem 1951, 193(1):265-275.

31. Lineweaver $H$, Burk D: The determination of enzyme dissociation constants. J Am Chem Soc 1934, 56:658-666.

32. Narjis $H$, Essam F, Anis M: Extraction and purification of urease from proteus mirabilis. Nat J Chemistry 2009, 33:138-145.

33. Fishbein WN, Nagaraja K, Scurzi W: Urease catalysis and structure .6. Correlation of sedimentation coefficients and electrophoretic mobilities for polymeric urease isozymes. J Biol Chem 1970, 245(22):5985.

34. Sung HY, Lee WM, Chiou MJ, Chang CT: A procedure for purifying jack bean urease for clinical use. Proc Natl Sci Counc Repub China B 1989, 13(4):250-257
35. Mirbod F, Schaller RA, Cole GT: Purification and characterization of urease isolated from the pathogenic fungus Coccidioides immitis. Med Mycol 2002, 40(1):35-44.

36. Smith PT, King AD, Goodman N: Isolation and characterization of urease from aspergillus-niger. J Gen Microbiol 1993, 139:957-962.

37. Ciurli S, Marzadori C, Benini S, Deiana S, Gessa C: Urease from the soil bacterium Bacillus pasteurii: Immobilization on Ca-polygalacturonate. Soil Biol Biochem 1996, 28(6):811-817.

38. Amin F, Bhatti HN, Asgher M: Partial purification and characterization of an acid invertase from saccharum officinarum I. Pak J Bot 2010, 42(4):2531-2540.

39. Srivastava PK, Kayastha AM, Srinivasan: Characterization of gelatin-immobilized pigeonpea urease and preparation of a new urea biosensor. Biotechnol Appl Biochem 2001, 34:55-62.

40. Muck RE: Urease activity in bovine feces. J Dairy Sci 1982, 65(11):2157-2163.

41. Rachhpalsingh, Nye PH: The effect of soil-ph and high urea concentrations on urease activity in soil. J Soil Sci 1984, 35(4):519-527.

42. Lal RB, Kissel DE, Cabrera ML, Schwab AP: Kinetics of urea hydrolysis in wheat residue. Soil Biol Biochem 1993, 25(8):1033-1036.

43. Loest RA: Urease from a sea-urchin lytechinus-variegatus - partial-purification and kinetics. Comp Biochem Physiol B 1979, 63(1):103-107.

44. Shepard MC, Luncefor C: Occurrence of urease in $t$ strains of mycoplasma. J Bacteriol 1967, 93(5):1513.

doi:10.1186/1471-2091-15-15

Cite this article as: EL-Hefnawy et al:: Extraction, purification, kinetic and thermodynamic properties of urease from germinating Pisum Sativum $L$. seeds. BMC Biochemistry 2014 15:15

\section{Submit your next manuscript to BioMed Central and take full advantage of:}

- Convenient online submission

- Thorough peer review

- No space constraints or color figure charges

- Immediate publication on acceptance

- Inclusion in PubMed, CAS, Scopus and Google Scholar

- Research which is freely available for redistribution 